\title{
VOLLEYBALL AS AN EXERCISE PROGRAM FOR OVERWEIGHT AND OBESE FEMALE ADOLESCENTS
}

\author{
VOLEIBOL COMO PROGRAMA DE EXERCÍCIOS PARA ADOLESCENTES COM SOBREPESO EOBESAS
}

Original Article

ARTIGO ORIGINAL Artículo Original

\section{EL VOLEIBOL COMO PROGRAMA DE EJERCICIO PARA ADOLESCENTES CON SOBREPESO Y OBESIDAD}

Luciana Prezotto Broglio' (iD (Physical Education Professional) Pamela Roberta Gomes Gonelli' (ID) (Physical Education Professional) Clauberto de Oliveira Costa' (iD (Physical Education Professional) Talita de Carvalho Sajorato' (ID) (Physical Education Professional) Vinicius Massarutto' (1D (Physical Education Professional) Marcelo de Castro Cesar ${ }^{2}$ (ID (Physician)

1. Universidade Metodista de Piracicaba - UNIMEP, Piracicaba, São Paulo, Brazil. 2. Universidade Federal de São Carlos - UFSCar, Piracicaba, São Paulo, Brazil.

\section{Correspondence}

Luciana Prezotto Broglio

Faculdade de Educação Física (UNIMEP), Piracicaba, SP, Brazil. 13400-911.

lucianaprezottobroglio@gmail.com

\begin{abstract}
Introduction: Sport is very important in the lives of children and adolescents, as it brings countless benefits at the physical, psychological and social levels. Objective: The aim of the study was to investigate the effects on physical fitness of an exercise program for overweight and obese female adolescents, with an emphasis on teaching volleyball. Methods: Twenty-five volunteers participated, aged between 13 and 14 years, of which 11 were overweight or obese for statistical analysis. Anthropometric and physical capacity assessments were performed, before and after 12 weeks, through activities related to volleyball. Results: There was an increase in height and span and a reduction in waist circumference, with no significant differences in body weight, BMl, arm circumference and triceps skinfold thickness; there was an increase in the sit-and-reach test, in the number of sit-ups and in the distance of the horizontal jump. There was a decrease in the time in the square test and the 20-meter run, with no significant differences in the medicine ball throw and in the 6-minute run test. Conclusion: It is concluded that the volleyball teaching program provided benefits for the physical fitness of overweight and obese adolescents. Level of evidence ll; Lower quality $R C T$ (example, $<80 \%$ follow-up, no randomization code masking or inadequate randomization).
\end{abstract}

Keywords: Adolescence; School; Volleyball; Health.

\section{RESUMO}

Introdução: O esporte émuito importante na vida de crianças e adolescentes, pois traz inúmeros benefícios físicos, psicológicos e sociais. Objetivo: O objetivo do estudo foi investigar os efeitos sobre a aptidão física de um programa de exercícios comênfase no ensino do voleibol para adolescentes do sexo feminino com sobrepeso e obesidade. Métodos: Participaram 25 adolescentes voluntárias com idade entre 13 e 14 anos, das quais 11 tinham sobrepeso ou eram obesas para análise estatística. Foram realizadas avaliações antropométricas e de capacidade física antes e depois de 12 semanas de atividades relacionadas a voleibol. Resultados: Verificou-se aumento de estatura eenvergadura e redução da circunferência da cintura, não ocorrendo diferenças significativas no peso corporal, no IMC, na circunferência do braço e na dobra cutânea tricipital. Houve aumento de flexibilidade no teste de sentar-e-alcançar, do número de abdominais e da distância do salto horizontal; verificou-se redução do tempo do teste de quadrado e do tempo da corrida de 20 metros, não ocorrendo diferenças significativas no arremesso de Medicine Ball e no teste de corrida de 6 minutos. Conclusão: Conclui-se que o programa de ensino de voleibol beneficiou a aptidão física das adolescentes com sobrepeso e obesidade. Nível de evidência ll; ECR de menor qualidade (por exemplo, $<80 \%$ de acompanhamento, sem mascaramento do código de randomização ou randomização inadequada).

Descritores: Adolescência; Escola; Voleibol; Saúde.

\section{RESUMEN}

Introducción: El deporte es muy importante en la vida de los niños y adolescentes, ya que aporta innumerables beneficios a nivel físico, psicológico y social. Objetivo: El objetivo del estudio fue investigar los efectos sobre la aptitud física de un programa de ejercicios con énfasis en la enseñanza del voleibol a adolescentes del sexo femenino con sobrepeso y obesidad. Métodos: Participaron veinticinco adolescentes voluntarias, de las cuales 11 tenían sobrepeso y obesidad para el análisis estadístico con edades comprendidas entre 13 y 14 años. Se realizaron evaluaciones antropométricas y de capacidad física, antes y después de 12 semanas de actividades relacionadas con el voleibol. Resultados: Hubo un aumento de la estatura y la envergadura y una reducción de la circunferencia de la cintura, sin diferencias significativas en el peso corporal, el IMC, la circunferencia del brazo y el pliegue cutáneo tricipital; se constató un aumento de flexibilidad en la prueba de "sentarsey alcanzar", en el número de abdominales yen la distancia del salto horizontal; hubo una disminución del tiempo en la prueba del cuadrado y en el tiempo de la carrera de 20 metros, sin diferencias significativas en el lanzamiento del balón medicinal y en la prueba de carrera de 6 minutos. Conclusión: Se concluye que el programa de enseñanza de voleibol benefició la aptitud física de las adolescentes con sobrepeso y obesidad. Nivel de evidencia ll; ECA de menor calidad (por ejemplo, $<80 \%$ de acompañamiento, sin enmascaramiento del código de aleatorización o aleatorización inadecuada).

Descriptores: Adolescencia; Escuela; Voleibol; Salud. 


\section{INTRODUCTION}

Sport is essential in the life of the child and of the adolescent, due to its importance in the individual's development and performance, as well as affecting society as a whole, through the competitiveness and sociability it brings. The school is a space of social learning, where special attention is due, favoring the process of participation and minimizing laziness and passivity and encouraging curiosity.

According to the Brazilian Institute of Geography and Statistics (IBGE) ${ }^{2}$ the school is an important space for spreading knowledge for children and young people to practice physical activity, in order to promote a healthy lifestyle, increasing their interest in the activities, sports and exercises practiced in Physical Education classes.

For adolescents, it is important to emphasize the role of recreation, sports in general and programmed physical activity, emphasizing strength and muscle resistance training. ${ }^{3}$ There are some students who do not engage in physical exercise very often. This carries a high risk in the health criteria for cardiorespiratory fitness, excess body weight and high blood pressure, exposing the individual to metabolic, cardiovascular and mental health disorders. ${ }^{4,5} \mathrm{~A}$ recent study found an association between physical inactivity during leisure time and in school, and the presence of common mental disorders in adolescents, indicating that sports, physical education in schools, and physical activity during leisure time can benefit adolescents' mental health. ${ }^{6}$

The practice of well-planned physical exercises can provide benefits for adolescents, such as: decreased adipose tissue and body mass, increased muscle mass, improved self-esteem, etc.?

Metabolic syndrome (MS) is a clinical condition involving anthropometric, physiological and biochemical abnormalities that increase the tendency, in affected individuals, to trigger type 2 diabetes and cardiovascular disease.

Among the various sports, volleyball is one that is popular throughout Brazil, ${ }^{9}$ it is played both competitively and for recreation, it is fast, exciting, and has lots of movement. ${ }^{10}$

Thus, physical preparation that can be developed in an organized and global way, focusing specifically on the motor skills for volleyball, with the aim of providing an overall foundation as part of the physical preparation, involving a set of physical exercises that result in physical training with harmonious, multilateral progression and improvements in health. ${ }^{11}$

Physical abilities, when explored through sport, both in physical preparation and in actual games or matches, affect physical performance by improving the individual's overall development. ${ }^{12,13}$ According to the literature, the intervention of 20 sessions of participation in sporting activities can provide adolescents with the opportunity to lean from experience and be able to practice sports independently. ${ }^{14}$

Adolescence is a phase that ranges from 10 to 19 years, a period that can contribute to the onset of obesity. ${ }^{14}$ This is in the context of over-consumption of food combined with an increasing sedentary lifestyle, which is linked to physical inactivity. ${ }^{15,16}$ A sedentary lifestyle is characterized by low levels of activity, and affects more than half of adolescents in Brazil living in medium and large cities, who do not achieve the recommended 300 minutes per week of physical activities that is recommended for good health. ${ }^{17,18}$ The prevalence of overweight and obesity in childhood and adolescence has a notable consequence in relation to low levels of physical fitness. ${ }^{19}$ Excess weight is affecting the young, school population earlier than ever, and physical inactivity is one of the determining factors for the accumulation of body fat. ${ }^{20}$

The practice of physical exercises leads to the improvement of physical skills and capabilities. ${ }^{21,22}$ Another important factor is the positive correlation between the improvement of physical and cognitive aspects in children and adolescents, and practitioners of physical exercise of the same age group. ${ }^{23}$

It is necessary to determine "national" standards in order to investigate the effects of sports practice on adolescents; thus, based on the Brazil Sport Project (PROESP-BR), ${ }^{24}$ which is a permanent observatory of indicators of growth and body development, motor and nutritional status of children and young people aged between 6 and 17 years, with the aim of assisting physical Education teachers in the evaluation of these indicators.

There is a lack of studies investigating the effects of physical exercise programs that complement physical Education in school, particularly through the intervention of volleyball. Hence, this study was carried out to evaluate the effects of a physical exercise program to improve the health of overweight and obese adolescents through the teaching and practice of volleyball.

\section{MATERIALS AND METHODS}

A program of physical exercises was carried out with an emphasis on the experience of volleyball. This study was approved by the Research Ethics Committee of Universidade Metodista de Piracicaba, under protocol number 49/13.

The parameters of the World Health Organization ${ }^{14}$ were used to classify body mass index and nutritional status values for children and adolescents.

The initial screening of this research comprised 155 female adolescents, and the evaluators conducted the screening of the adolescents in the schools, through the collection of anthropometric data.

After the screening and categorization of adolescents based on the $\mathrm{BMI}$ classification, according to the $\mathrm{WHO}^{14}$ the adolescents were invited to participate in the exercise program proposed by the research. Of this population evaluated, 50 adolescents entered the program and 25 participated effectively in all the evaluation stages and in the 12 weeks of exercises.

The volunteers attended physical education classes in state schools, with two 50-minute classes that took place simultaneously or on alternate days.

Of the participants, 14 were classified as eutrophic; 5 presented BMI with a percentile greater than 85 , indicating overweight and 6 presented BMI with a percentile greater than 97, indicating obesity.

The volunteers' parents/guardians signed an informed consent form. The exclusion criteria were: schoolchildren who did not want to participate in the project and/or whose parents/guardians did not authorize their participation, the presence of chronic diseases, the practice some form of physical exercises other than the school physical education classes, and attendance of less than $80 \%$ of classes during the program.

The measures were carried out before and after the intervention. Anthropometric measurements (body mass, height, span, triceps skinfold, right arm circumference and waist circumference) and calculation of BMI were performed, as well as physical capacity tests: flexibility in the sit-and-reach test, localized muscle resistance in the sit-up test (one minute), explosive strength of the upper limbs with a medicine ball (two $\mathrm{kg}$ ), explosive strength of the lower limbs with the horizontal jump, agility with the square test, speed with the 20 meter race test and cardiorespiratory parameters with the 6-minute run/walk test as per PROESP-BR. ${ }^{24}$

The activities were carried out in the sports hall of a partner institution. The exercise program with emphasis on teaching volleyball consisted of 12 weeks with 24 sessions, with physical exercises emphasizing volleyball with teaching techniques of the serve, forearm pass (bump), touch and block; the tactical part of the game, and the competitive games between 
the girls of the program and with the students of the undergraduate course of physical education.

The classes were taught on two days a week, with each class lasting 90 minutes. The intervention program was divided into three parts: a) warm-up; b) the class itself; c) cooling down.

The warm-up included static and dynamic exercises, involving rhythm using music, as well as activities and playing games, lasting 15 minutes. The class itself included exercises that focused on physical preparation involving physical skills and abilities with work on strength, speed, resistance, motor coordination, flexibility, agility and balance. This part lasted 50 minutes.

During the game, the researchers analyzed and observed the degree of learning and its applicability. These games were adapted to involve doubles, trios, or foursomes, as well adding the rule that the ball could bounce once on the ground, or be caught before being released to the opponents.

The classes ended with a cooling-down period consisting of some stretching, in what was a more relaxed moment.

In the rounds of discussions, subjects of interest to the group were discussed, such as care of the body, obesity, posture, and diet. This was a time for the researchers and students to interact, bringing together girls of different ages, from different schools and classrooms. The importance of the round of discussions was demonstrated by the levels of responsibility, interest in what was discussed in the group, and mutual respect observed. ${ }^{25}$

\section{Statistical analysis}

For the analysis of the results, we performed central trend measurements, the Shapiro Wilk's test to verify the normality of the data, for the parametric data, the Student's t test was performed for dependent samples and for the non-parametric data, the Wilcoxon test was applied. The level of significance was $p<0,05$. The data were processed in Bioestat 5.3.

\section{RESULTS}

Table 1 shows the results of the anthropometry tests; there was an increase in height and span, and a reduction in waist circumference, with no significant differences in body mass, BMI, triceps skinfold and arm circumference.

In the physical capacity tests, there was an increase in the distance reached in the sit-and-reach test, in the number of sit-ups, and in the distance reached in the horizontal jump, and there was a decrease in the time in the square test and in the 20-meter run time. There were no significant changes in the medicine ball test and the 6-minute walk/ run test (Table 2).

\section{DISCUSSION}

The results of the increase in height and span were expected, in accordance with the age group of the volunteers. Although there was no decrease in body mass, the reduction in waist circumference is an

Table 1. Mean, standard deviation and statistical analysis of the anthropometry pre- and post-program of exercises for adolescents with excess body weight $(n=11)$.

\begin{tabular}{c|c|c}
\hline Variables & Pre & Post \\
\hline Body weight $(\mathrm{kg})$ & $67.14 \pm 5.14$ & $67.03 \pm 4.96$ \\
\hline Height $(\mathrm{cm})$ & $157.5 \pm 6.29$ & $158.14 \pm 6.03^{*}$ \\
\hline BMl $\left(\mathrm{kg} / \mathrm{m}^{2}\right)$ & $27.11 \pm 2.24$ & $26.87 \pm 2.39$ \\
\hline Span $(\mathrm{cm})$ & $170 \pm 0.16$ & $171 \pm 0.16^{*}$ \\
\hline Skinfold Thickness $(\mathrm{mm})$ & $30.91 \pm 5.54$ & $29.64 \pm 6.09$ \\
\hline Circumference RA $(\mathrm{cm})$ & $30.55 \pm 2.72$ & $30.00 \pm 3.11$ \\
\hline Circumference W $(\mathrm{cm})$ & $83.05 \pm 6.83$ & $79.64 \pm 4.76^{*}$ \\
\hline Kg- - kilogram; $\mathrm{m}$ - meters; $\mathrm{cm}$ - centimeters; $\mathrm{kg} / \mathrm{m}^{2}$ - kilograms per square meter; $\mathrm{mm}$ - millimeters; $\mathrm{RD}$ - right arm;
\end{tabular}

C- waist; * $p<0.05$
Table 2. Mean, standard deviation and statistical analysis of the physical tests preand post-program of exercises for adolescents with excess body weight $(n=11)$.

\begin{tabular}{c|c|c}
\hline Variables & Pre & Post \\
\hline SAR $(\mathrm{cm})$ & $30.11 \pm 4.28$ & $33.37 \pm 3.31^{*}$ \\
\hline Sit-ups (reps) & $19.82 \pm 3.68$ & $23.36 \pm 3.04^{*}$ \\
\hline Medicine ball $(\mathrm{cm})$ & $321 \pm 0.32$ & $314 \pm 0.21$ \\
\hline Horizontal jump (cm) & $123 \pm 0.16$ & $129 \pm 0.14^{*}$ \\
\hline Square (s) & $6.64 \pm 0.52$ & $6.26 \pm 0.32^{*}$ \\
\hline 20-meter RUN (s) & $4.12 \pm 0.42$ & $3.81 \pm 0.34^{*}$ \\
\hline 6-minute RUN/WALK (m) & $886.89 \pm 123.61$ & $874.16 \pm 76.01$ \\
\hline SAR-sit-and-reach; RUN/WALK; rep - repetitions; $\mathrm{cm}$ - centimeters; $\mathrm{m}$ - meters; - seconds; ${ }^{*} \mathrm{p}<0.05$.
\end{tabular}

important benefit, since waist circumference is related to metabolic syndrome, according to a study of cardiovascular risks in adolescents (ERICA), a national study based in schools. ${ }^{26}$

In the physical capacity tests of the PROESP-BR, ${ }^{24}$ the increase in the distance reached in the sit and reach test indicates improvement in flexibility; the number of sit-ups shows improvement in localized muscle resistance (LMR); the greater distance reached in the horizontal jump indicates improvement in the strength of the lower limbs; the shorter time in the square test indicates improved agility and the faster times in the 20-meter race point to improved speed.

There were no significant changes in the medicine ball test to verify the strength of the upper limbs, and in the six-minute walk/run test to verify cardiorespiratory resistance, therefore, these variables were not influenced by the program.

Bróglio ${ }^{27}$ investigated the effects of a physical exercise program with emphasis on volleyball in overweight and obese girls aged between 11 and 15 years, divided into an intervention group $(n=13)$ and a control group ( $n=13$ ). The intervention group participated in the program, which had 40 sessions, twice a week, in addition to the physical education classes. The control group took part only in the physical education classes. The two groups were submitted to anthropometric assessments and physical capacity tests (PROESP-BR). In the intervention group, the anthropometry showed an increase in height and span, and a decrease in waist and right arm circumference, and no significant differences in body mass, BMI and triceps skinfold. There was an improvement in physical capacities in the results of the sit-and-reach test, sit-ups test, horizontal jump, medicine ball throw, square, 20-meter running and 6-minute running/walking; in the control group, the duration of the program was the same, in anthropometry there was an increase in body mass, height, span and triceps skinfold, with no significant differences in BMI and arm and waist circumferences, and in physical capacities there were no significant differences in the tests results. It was concluded that the physical exercise program, with the intervention of volleyball, brought benefits for the physical fitness of overweight and obese adolescents, which is in accordance with the results of this study.

The practice of physical exercises can promote the learning of motor skills, providing a basis of understanding for more complex learning. ${ }^{28}$ Volleyball is a collective sport in which the players rely heavily on the actions of their teammates. Therefore, the players are forced to cheer each other on, leading to socialization in a natural way.

The 24 sessions collaborated in the teaching learning process being analyzed in the friendly games, in the motivation to get it right, from the initial serve through to the end of the game, which corroborates what is described in the program 2nd Time, that for learning, at least 20 sessions are needed. ${ }^{13}$

In the teaching and practice of volleyball, it was considered that there was improvement in the adolescents in some aspects, as observed in loco by the researchers through the game play, the positive development of each one in participation in order not to let the ball fall the ground; in serving 
the ball to the other side of the court, in hitting the ball into the opponent's court, and through the tests that were conducted after the 24 sessions.

Sports can bring health benefits, and motivate adolescents to spend time with friends during practice; to this end, it should be considered that for females with excess weight, physical activity of three to six hours per week is important, as well as participating in physical education classes and reducing sedentary behavior.

There is a need to mobilize, stimulate and raise awareness among adolescents, by encouraging sports and physical exercises before, during and after time in school, as tools for improving health, education, and leisure so that in the long term, they can develop healthy habits into adulthood. In this research, the importance of social interaction, respect and friendship among eutrophic, overweight and obese adolescents was highlighted.

A limitation of this study is that it did not have a control group for comparison with the volunteers submitted to intervention. However, as in the study by Bróglio, ${ }^{27}$ no benefits were observed in overweight and obese adolescents who participated only in physical education classes, the improvements obtained in the present study can be attributed to participation in the physical exercise program with emphasis on volleyball.

\section{CONCLUSION}

It was verified that the exercise program with emphasis on teaching volleyball, carried out in a targeted way, brought benefits in anthropometry, with the reduction of waist circumference, and in physical capacities, with improvement of flexibility, abdominal muscle resistance, lower limb strength in agility and speed.

Observing the learning of sport for overweight and obese adolescents, the intervention provided an improvement in anthropometry and in the performance of physical capacities that are important for health and for a more active life.

All authors declare no potential conflict of interest related to this article

AUTHORS' CONTRIBUTIONS: Each author made significant individual contributions to this manuscript. LPB (0000-0003-1668-0920): elaboration of the entire research project, bibliographic review, collection, analysis and interpretation of the data, writing and critical review of the article; PRGG: collection, analysis, statistics and interpretation of the data, writing and review of the article; COC: collection, analysis and interpretation of the data, writing, critical review of the article, formatting; TCS: collection of data, critical review of the article; VM: collection of data, critical review of the article; MCC: intellectual concept, elaboration of the research project, analysis and interpretation of the data, writing and critical review of the article. All authors reviewed the article before submission and approved the final version of the article.

\section{REFERENCES}

1. Rodrigues HA, Darido SC. O livro didático na Educação Física escolar: a visão dos professores. Motriz Rev. Ed. Fis. 2011 Jan/Mar;17(1):48-62.

2. IBGE. Pesquisa Nacional de Saúde do Escolar. [Internet]. 2009 [acesso em 2016 Mar 22]. Disponível em: www.ibge.gov.br/home/estatistica/populacao.

3. Sociedade Brasileira de Pediatria. Obesidade na infância e na adolescência- Manual de orientação São Paulo: SBP; 2008.

4. Coledam DHC, Ferraiol PF, Pires Junior R, Santos JW, Oliveira AR. Prática esportiva e participação nas aulas de educação física: fatores associados em estudantes de Londrina, Paraná, Brasil. Cad. Saúde Pública. 2014 Mar;30(3):533-45.

5. Cordeiro JP, Dalmaso SB, Anceschi SA, Sá FGS, Ferreira LG, Cunha MRHea. Hipertensão em estudantes da rede pública de vitória/es: influência do sobrepeso e obesidade. Rev. Bras. Med. Esporte. $2016 \mathrm{Jan} /$ Fev;22(1):59-65.

6. Ferreira VR, Jardim TV, Póvoa TIR, Viana RB, Sousa ALL, Jardim PCV. Inatividade física no lazer e na escola está associada à presença de transtornos mentais comuns na adolescência. Rev. Saúde Pública. 2020 Dez;54(128):1-10

7. Santos GO, Bagestão VS, Silva SL. Efeitos dos Exercícios físicos em crianças e adolescentes. Braz. J. of Dev. 2021 Jan;7(1):8903-8915.

8. Sociedade Brasileira de Pediatria. Obesidade na infância e adolescência - Manual de Orientação. 2nd ed. São Paulo: SBP; 2012.

9. Magarotto Junior L, Depra P. Validação de lista para análise qualitativa da recepção no voleibol. Revista Motriz. $2010 \mathrm{Jul} / \mathrm{Set} ; 16(3): 571-9$.

10. Bojikian JCM, Bojikian LP. Ensinando Voleibol. 5th ed. São Paulo: Phorte; 2012

11. Rhea M. Treinamento de força para crianças São Paulo: Phorte; 2009.

12. Petroski EL, Silva AF, Rodrigues AB, Pelegrini A. Aptidão física relacionada a saúde em adolescentes brasileiros residentes em áreas de médio/baixo índice de desenvolvimento humano. Rev. Salud pública. 2011;13(2):219-228.

13. Gonsález FJ, Darido SC, Oliveira AAB. Esporte de marca e com rede divisória ou muro/parede de rebote: badminton, peteca, tênis de campo, tênis de mesa, voleibol, atletismo. Maringá: Eduem; 2014.

14. WHO - World Health Organization. The WHO Child Growth Standards. [Internet]. 2007 [acesso em 2014 Dez 10]. Disponível em: http://www.who.int/childgrowth/en.

15. Dias PJP, Domingos IP, Gonçalves FM, Paula MA, Rosely S, Veras GSRM. Prevalência e fatores associados aos comportamentos sedentários em adolescentes. Rev. Saúde Pública. 2014;48(2):266-274

16. Lima NN, Silva RU, Pompílio RGS, Queiroz DR, Freitas CMSM. Perfil sociodemográfico e de atividade física em adolescentes escolares. Rev. Bras. Ciên. Saúde. 2014 Jan/Mar;39:1-7.

17. Cureau FV, Silva TLN, Bloch KV, Fujimori E, Belfort DR, Carvalho KMB, et al. ERICA: inatividade física no lazer em adolescentes brasileiros. Rev. Saúde Pública. 2016;50(4s):1s-11s.

18. Soares CAM, Hallal PC. Interdependência entre a participação em aulas de Educação Física e níveis de atividade física de jovens brasileiros: etudo ecológico. Rev. bras. educ. fís. esporte. 2015 Nov;20(6):588-594

19. Marques KC, Silva PT, Tornquist D, Muradás R, Schwanke NL, Burgos LT, et al. Programa de intervenção com exercício físicos melhora indicadores de aptidão física relacionada à saúde e ao desempenho motor em escolares com sobrepeso e obesidade. Cinergis. 2014 Jul/Set;15(3):118-122.

20. Bastos F, Reis VM, Aranha ÁC, Garrido ND. Relação entre atividade física e desportiva, níveis de IMC, percepções de sucesso e rendimento escolar. Motri. 2015;11(3):41-58.

21. Walther C, Gaede L, Adams V, Gelbrich G, Leichtle A, Erbs S, et al. Effect of Increased Exercise in School Children on Physical Fitness and Endothelial Progenitor Cells A Prospective Randomized Trial. Journals Pedriatric Cardiology. 2009 Dez;7(3):2251-9.

22. Lee YH, Song YW, Kim HS, Lee SY, Seony JH, Suh SH, et al. The effects of an exercise program on anthropometric, metabolic, and cardiovascular parameters in obese children. Korean Circ J. 2010;40(4):179-184

23. Davis E, Pitchford N, Limback E. The interrelation between cognitive and motor development in typically developing children aged 4-11 years is underpinned by. Brit. J. Psychol. 2011;102(3):569-84.

24. PROESP-BR - Projeto Esporte Brasil. Manual de aplicação de medidas e testes, normas e critérios de avaliação. [Internet]. 2012 [acesso em 2014 Ago 18]. Disponível em: http://cev.org.br/arquivo/biblioteca/ manual-testes-avaliacao-proesp-versao-2012.pdf.

25. Diniz IKS, Rodrigues HA, Darido SC. Os Usos da mídia em aulas de Educação Física escolar: possibilidades e dificuldades. Rev. Mov. 2012 Jul/Set;18(3):183-202.

26. Bloch KV, Henrique KC, Moyses S, C KMC, Azevedo AG, Augusta BL, et al. ERICA: prevalências de hipertensão arterial e obesidade em adolescentes brasileiros. Rev. Saúde Pública. 2016;50(9s):1s-3s.

27. Bróglio LP. Programa de exercícios físicos para adolescentes com sobrepeso e obesas: estudo com voleibol. [tese (Doutorado em Ciências do Movimento Humano)]. Piracicaba: Universidade Metodista de Piracicaba; 2017.

28. Fernandes MM, Penha DSGP, Assis BF. Obesidade infantil em crianças da rede pública de ensino: prevalência e consequências para flexibilidade, força explosiva e velocidade. Rev. Educ. Fis. 2012;23(4):629-634. 